Proc. Estonian Acad. Sci. Biol. Ecol., 2002, 51, 2, 124-137

\title{
New records of aphids (Homoptera, Aphidodea) from Estonia
}

\author{
Tarmo Tiido
}

Institute of Zoology and Hydrobiology, University of Tartu, Vanemuise 46, 51014 Tartu, Estonia; ttiido@hotmail.com

Received 30 March 2001, in revised form 27 September 2001

\begin{abstract}
According to the literature reports 185 species of aphids (Homoptera, Aphidodea) have been found in Estonia. In this paper additional material on 55 aphid species new to Estonia is presented. From species new to Estonia Aphis forbesi Weed, A. newtoni Theob., A. praeterita Wlk., Anuraphis catonii H.R.L., Brachycaudus tragopogonis (Klt.), Dysaphis bonomii (H.R.L.), and D. devecta (Wlk.) probably have the northern border of their distribution area here. Macrosiphum trollii Börn. is a boreoalpine species. It has been found in Finland but not in Latvia and Lithuania.
\end{abstract}

Key words: Homoptera, Aphidodea, Estonia, new records.

\section{INTRODUCTION}

Aphids are small insects that feed on the phloem fluid of plants. Many species of aphids attack important agricultural crops and are, therefore, of major economic importance.

Most aphids are monoecious, living on one or a few species of a particular genus of plants. About $10 \%$ are heteroecious spending autumn, winter, and spring on one plant species (its primary host) and summer on a different unrelated plant (its secondary host).

In a holocyclic life cycle both asexual and sexual morphs are produced at different times of the year. In contrast, anholocyclic species produce only asexual females. They do not produce sexual females and males.

So far 4425 species of aphids (suborder Aphidodea, order Homoptera) have been described worldwide (Heie, 1995b). The suborder Aphidodea is divided into two superfamilies, Phylloxeroidea and Aphidoidea. Scandinavian fauna consists of about 20 species of Phylloxeroidea and 616 species of Aphidoidea (Heie, 1995b). Species found in Finland include about $68 \%$ of all aphids found in 
Scandinavia (Heie, 1995b), i.e. over 400 species. The faunistic review of Latvia by Rupais (1989) includes 382 species of Aphidodea.

In Estonia, the only well-researched homopterans are the cicadas (Cicadinea). According to unpublished data of J. Vilbaste 312 species have been found (as mentioned in Elberg, 1995). Unfortunately, research into other homopterans, including aphids, has been rather slack. It can be explained by the fact that those few scientists who have done research into aphids in Estonia have been foreigners and stayed in Estonia for a short time. The main focus has been on aphids residing on woody plants.

The investigation of the Estonian Aphidodea was started by N. Cholodkovsky. In various publications (Cholodkovsky, 1897a, 1897b, 1898a, 1898b, 1902) he mentions, among the others, aphids collected from Meriküla, Vaivara, and NarvaJõesuu (Hungerburg) in the years 1892-96. In the register of aphids Cholodkovsky (1902) entered 73 species that he found in Estonia.

A Latvian researcher Opmanis (1928) registered 19 species of dendrophilous aphids (of which 6 were found in Estonia for the first time) in the vicinity of Valga.

Knowledge of Estonian aphids improved notably as a result of the research work led by a Latvian aphidologist, A. Rupais. In the years 1965-66, the Botanical Garden of the Latvian SSR Academy of Sciences organized several expeditions to Estonian parks, and during those expeditions he collected aphids from trees and bushes. The research paper by Rupais (1968) contains 32 species. The list published later (Rupais, 1972) is more complete, including 137 species of dendrophilous aphids from Estonia.

Some species are also mentioned by Vilbaste (1979), Rupais \& Juronis (1984), Haberman et al. (1985), Kruus (1988), Rupais (1989), and Elberg (1992). There are also some publications on forestry and plant protection that contain references on aphids (Daniel, 1935; Lepik \& Zolk, 1937; Maavara et al., 1961; Jaama et al., 1973; Kuusksalu et al., 1982).

In accordance with the above-mentioned publications, the total number of species found in Estonia is 185.

\section{MATERIAL AND METHODS}

The material for the present work was provided by original research in 1992, 1997, and 1998. A total of 473 samples were collected and one to five individuals from each sample were examined. The data were obtained mainly from Tartu (in the first place, from the Botanical Garden of the University of Tartu), a few from Taevaskoja (Põlva county), Kõnnu (Harju county), Palmse (Lääne-Viru county), and Tähtvere (Tartu county). The material is deposited in the author's collection.

This paper lists 55 species of aphids, which are new for the fauna of Estonia. For the new species the following information is given: locality, UTM $10 \times 10 \mathrm{~km}$ grid reference, and name of the county (in brackets), date of collection, the morphs found, the records of the host plant, and details of the biology. The 
nomenclature and arrangement of the taxa are presented according to Heie (1980, 1982, 1986, 1992, 1994, 1995a). If a species probably reaches the northern limit of its distribution area on the territory of Estonia (absent in Finland, in Sweden, or in both countries), an asterisk precedes the name of the species in the list. In that case, the species is provided with comments following the checklist.

Data on the biology and distribution of aphids are based on Heie (1980, 1982, 1986, 1992, 1994, 1995a), if not shown otherwise.

The following abbreviations are used: $\mathrm{al}=$ alate viviparous female; apt $=$ apterous viviparous female.

\section{RESULTS}

As a result of this work 168 species of aphids belonging to the families Mindaridae, Thelaxidae, Anoeciidae, Pemphigidae, Drepanosiphidae, and Aphididae of the superfamily Aphidoidea were established, 55 of them are new to Estonia. Aphids were found on 284 plant species. Adding the species of aphids found by the author as new in Estonia to the formerly registered 185 species, we get a total of 240 aphid species known in Estonia.

Information on aphid species and subspecies of Estonia can be regarded as rather poor, especially when compared to respective species numbers of Latvia and Finland. At present, the largest local list is that of the Tartu area, which includes 168 species. For the majority of species the number of records is not sufficient to establish approximate limits of ranges and to assess the frequency of occurrence in Estonia.

\section{Aphid species new to Estonia}

\section{THELAXIDAE}

1. Glyphina schrankiana Börner, 1950: Taevaskoja (NE03, Põlva county), 11.VII.1992, 3 apt on Alnus sp.

The aphids were collected on a young shoot of Alnus sp. They were attended by ants.

Biology: The species lives monoeciously on Alnus.

\section{ANOECIIDAE}

2. Anoecia vagans (Koch, 1856): Tartu (ME87), 20.VII.1998, 2 apt and 2 al on Poaceae sp.

The aphids were found on roots of Poaceae sp., accompanied by Anoecia corni (F.). They were attended by ants.

Biology: The species is heteroecious with Cornus as the primary host, and grasses (e.g. Elytrigia, Hordeum, and Triticum) as the secondary hosts. They feed on the leaves of Cornus and on roots of grasses. 


\section{PEMPHIGIDAE}

3. Pemphigus borealis Tullgren, 1909: Tartu (ME87), 09.VII.1998, galls with 3 al and 2 nymphs with wing buds on Populus balsamifera; 27.VIII.1998, 3 alate sexuparae on P. balsamifera; 12.IX.1998, galls and 2 nymphs (al) on $P$. suaveolens.

Many galls bearing alate viviparous females and nymphs inside were found in groups of two or three on the branches of P. balsamifera. In late August, alate sexuparae were found on the trunk of the same tree. In September galls were found on $P$. suaveolens; one of them bore 2 alate nymphs inside.

Biology: The species is host alternating between Populus and roots of Bidens. Oval galls of hazel-nut size are formed at the branches of Populus, in Sweden on P. laurifolia and P. balsamifera (Heie, 1980), in Latvia also on P. trichocarpa and $P$. $\times$ berolinensis (Rupais, 1989).

4. Forda formicaria von Heyden, 1837: Tartu (ME87), 30.V.1998, 5 apt on Alopecurus pratensis.

Biology: The species lives anholocyclically on roots of various grasses, e.g. Agrostis, Dactylis, Elytrigia, Festuca, and Poa. The aphids are attended by ants and hibernate in ant's nests.

A small colony of apterous viviparous females was found on roots of Alopecurus pratensis. They were attended by ants.

5. Forda marginata Koch, 1857: Tartu (ME87), 23.VII.1998, 4 apt on Poa pratensis.

The species seems to prefer sunny and rather dry places, as pointed out by Heie (1980): small colonies were found on roots of $P$. pratensis growing in warm and sandy soil. They were attended by ants.

Biology: The species lives anholocyclically on roots of various grasses, e.g. Agrostis, Dactylis, Elytrigia, Festuca, and Poa. The aphids are attended by ants and hibernate in ant's nests.

\section{DREPANOSIPHIDAE}

6. Therioaphis riehmi (Börner, 1949): Tartu (ME87), 19.VII.1998, 2 al and 2 nymphs (al) on Melilotus albus.

The aphids were found singly or in small colonies on undersides of leaves of M. albus.

Biology: The species lives monoeciously on Melilotus, especially M. albus.

7. Chaitophorus ramicola (Börner, 1949): Tartu (ME87), 19.VII.1998, 5 apt on Salix caprea.

The small colony was found on a young twig of S. caprea. The aphids were attended by ants.

Biology: The species lives monoeciously on Salix caprea and S. cinerea. In Finland it has also been found on S. aurita and S. phylicifolia (Heikinheimo, 1997). 
8. Sipha elegans del Guercio, 1905: Tartu (ME87), 06.VII.1998, 3 apt and 1 al on Elytrigia repens.

The aphids were collected on the upper sides of leaves of E. repens.

Biology: The species lives monoeciously on Elytrigia repens. It has also been found on several other grasses such as Festuca, Hordeum, Arrhenatherum, and Triticum.

\section{APHIDIDAE}

9. Schizaphis caricis (Schouteden, 1906): Tartu (ME87), 12.VII.1998, 1 apt on Carex pseudocyperus.

Only one specimen (apt) was collected on a leaf of C. pseudocyperus.

Biology: The aphids live on Carex and Scirpus, also on subterranean parts, and are visited by ants.

10. Aphis craccae Linné, 1758: Tartu (ME87), 08.VII.1997, 3 apt on Vicia cracca; Kõnnu (MF29, Harju county), 31.VII.1997, 3 apt on V. cracca.

The small colonies were found on pedicels of inflorescences of $V$. cracca.

Biology: The species lives monoeciously on Vicia cracca.

11. Aphis epilobiaria Theobald, 1927: Tartu (ME87), 16.VII.1997, 3 apt and 2 al on Epilobium hirsutum; Palmse (MF49, Lääne-Viru county), 30.VII.1997, 4 apt on E. hirsutum.

The aphids were found on pedicels of E. hirsutum.

Biology: The species lives monoeciously in inflorescences, on upper parts of stems and young leaves of Epilobium hirsutum.

12.*Aphis forbesi Weed, 1889: Tartu (ME87), 02.VIII.1998, 2 apt, 1 al, and 3 nymphs (apt) on Fragaria sp.

The small colony was found on a leaf petiole of Fragaria sp. The aphids were attended by ants.

Biology: The species lives monoeciously on bases of leaf petioles or on flowering shoots of Fragaria.

13.*Aphis newtoni Theobald, 1927: Tartu (ME87), 18.VII.1997, 3 apt and 2 al on Iris sp., 20.VII.1997, 2 apt and 2 al on I. bloudowii, I. latifolia, I. spuria, and Tigridia pavonia.

The colonies situated near ground level were found on both sides of leaves. They were attended by ants. The fact that this species fed on T. pavonia, which also belongs to Iridaceae, shows that its host specificity may be occasionally broader.

Biology: The species lives monoeciously on Iris.

14. Aphis podagrariae Schrank, 1801: Tartu (ME87), 02.VII.1998, 1 apt, 1 al, and 3 nymphs (al) and 24.VII.1998, 2 apt on Aegopodium podagraria.

The aphids were found on leaf nests of A. podagraria. They were attended by ants. 
Biology: The species lives monoeciously on Aegopodium podagraria in tightly curved leaves.

15.*Aphis praeterita Walker, 1849: Tartu (ME87), 23.VII.1997, 2 apt on Epilobium hirsutum; Palmse (MF49, Lääne-Viru county), 30.VII.1997, 2 apt on E. hirsutum.

The aphids were found mainly along the midribs on the underside of lower leaves of $E$. hirsutum; these had turned yellowish.

Biology: The species lives monoeciously on Epilobium hirsutum. It has also been found on E. palustre and E. parviflorum.

16. Aphis rumicis Linné, 1758: Tartu (ME87), 11.VII.1997, 2 apt on Rumex alpinus.

The large colony was found on the underside of a leaf of $R$. alpinus.

Biology: The species lives monoeciously on Rumex.

17. Aphis schneideri (Börner, 1940): Tartu (ME87), 11.VII.1997, 2 apt on Ribes nigrum.

The small colony was found on the underside of slightly curled leaves in a terminal shoot of $R$. nigrum. The aphids were attended by ants.

Biology: The species lives monoeciously on Ribes nigrum. R. rubrum and $R$. alpinum can also serve as hosts.

18. Aphis taraxacicola (Börner, 1940): Tartu (ME87), 02.VIII.1998, 3 apt and 2 nymphs (al) on Taraxacum officinale; 07.VII.1997, 2 apt and 08.VII.1998, 3 apt on T. officinale.

The aphids were collected on subterranean stems and leaf bases of T. officinale. They were attended by ants.

Biology: The species lives monoeciously on Taraxacum.

19. Aphis ulmariae Schrank, 1801: Tartu (ME87), 20.VII.1998, 3 apt on Filipendula ulmaria; Taevaskoja (NE03, Põlva county), 11.VII.1992, 2 apt on F. ulmaria.

The colonies of small or medium size were found on leaf nests, and were visited by ants.

Biology: The species is monoecious. On Filipendula ulmaria the leaves are curled into leaf nests containing the colonies, which are visited by ants.

20. Aphis umbrella (Börner, 1950): Tartu (ME87), 16.VII.1997, 3 apt and 06.VIII.1997, 2 apt on Hibiscus trionum; 09.VII.1997, 2 apt and 18.VII.1997, 2 apt and 2 al on Malva moschata; 16.VII.1997, 3 apt on Sidalcea oregana.

The colonies were found on leaf nests of H.trionum, M. moschata, and $S$. oregana. The aphids were visited by ants. Finding the colonies on H. trionum and $S$. oregana (both belong to Malvaceae) indicates their suitability as host plants of A. umbrella.

Biology: The species lives monoeciously on Malva. 
21. Toxopterina vandergooti (Börner, 1939): Tartu (ME87), 21.VI.1998, 2 apt and 1 nymph (al) on Achillea millefolium; 08.VII.1998, 2 apt on Tanacetum vulgare.

The aphids were found on roots and subterranean stems of A. millefolium and T. vulgare. They were attended by ants. According to Rupais (1989) this species is rare in Latvia. At least in Tartu, T. vandergooti seems to be common; it was found from various places in the town.

Biology: The species lives monoeciously on subterranean parts of various composites, e.g. Achillea millefolium, Matricaria, Tanacetum, and Tussilago farfara.

22.*Anuraphis catonii Hille Ris Lambers, 1935: Tartu (ME87), 17.VII.1998, 1 al on Pimpinella saxifraga.

One alate female and larvae were found on a subterranean stem of $P$. saxifraga.

Biology: The species is heteroecious alternating between Pyrus and Pimpinella, especially P. saxifraga. On the primary host Pyrus, these aphids are found in folded leaves. On Pimpinella, the colonies occur at the ground level.

23. Brachycaudus populi (del Guercio, 1911): Tartu (ME87), 25.VII.1998, 1 apt on Silene maritima.

Only one specimen (apt) was collected on a stem of S. maritima.

Biology: The species lives monoeciously on Silene.

24.*Brachycaudus tragopogonis (Kaltenbach, 1843): Tartu (ME87), 22.VII.1998, 3 apt and 1 al on Tragopogon pratensis; 26.VII.1998, 3 apt on T. orientalis.

The colonies of small or medium size were found on leaf sheaths of T. orientalis and $T$. pratensis, and were visited by ants.

Biology: The species lives monoeciously on Tragopogon pratensis.

25.*Dysaphis bonomii (Hille Ris Lambers, 1935): Tartu (ME87), 08.VII.1998, 3 apt on Pastinaca sativa subsp. sylvestris.

The small colony was found on the subterranean part of the stem of $P$. sativa subsp. sylvestris. It was attended by ants.

Biology: The species lives monoeciously on Pastinaca sativa.

26.*Dysaphis devecta (Walker, 1849): Tartu (ME87), 19.VI.1998, 2 apt, 2 nymphs (al), and 1 al on Malus domestica.

Many reddish roll-galls bearing apterous (incl. alatiform) viviparous females and nymphs (al) inside were found on $M$. domestica.

Biology: The species lives monoeciously in marginal roll-galls on the leaves of Malus.

27. Hayhurstia atriplicis (Linné, 1761): Tartu (ME87), 04.VII.1997, 2 apt on Chenopodium album.

Leaf galls were found on the upper and lower leaves of C. album.

Biology: The species lives monoeciously on pod-like yellowish leaf galls of members of Chenopodiaceae, e.g. Chenopodium album, Atriplex hastata, and A. patula. 
28. Lipaphis erysimi (Kaltenbach, 1843): Tartu (ME87), 24.VII.1998, 3 apt on Capsella bursa-pastoris.

The aphids were collected on fruits of $C$. bursa-pastoris.

Biology: The species lives monoeciously on many genera of Brassicaceae, e.g. Capsella, Sinapis, Sisymbrium, and Thlaspi.

29. Hyadaphis sphondylii (Koch, 1854): Tartu (ME87), 09.VI.1998, 3 apt and 15.VII.1997, 2 apt and 1 al on Aegopodium podagraria; 17.VII.1998, 1 al on Pimpinella saxifraga; 25.VII.1998, 2 apt on Heracleum mantegazzianum.

The aphids were found on leaf sheaths of A. podagraria and in inflorescences of $P$. saxifraga. On $H$. mantegazzianum representatives of the species were recorded in a mixed colony with Aphis fabae Scop. and Cavariella pastinacae (L.). The aphids were attended by ants.

Biology: The species is heteroecious with Lonicera as the primary host, and Angelica and other Apiaceae as the secondary hosts.

30. Hydaphias hofmanni Börner, 1950: Tartu (ME87), 04.VII.1998, 2 apt and 05.VII.1998, 3 apt on Galium verum.

The colony of medium size was found on a deformed shoot of G. verum. It was attended by ants.

Biology: The species lives monoeciously on Galium verum.

31. Coloradoa achilleae Hille Ris Lambers, 1939: Tartu (ME87), 02.VII.1998, 2 apt on Achillea millefolium.

Two specimens were found singly on the underside of a leaf of its host.

Biology: The species lives monoeciously on Achillea millefolium.

32. Coloradoa artemisiae (del Guercio, 1913): Tartu (ME87), 22.VII.1998, 1 apt on Artemisia vulgaris.

Only one specimen (apt) was collected in inflorescences of A. vulgaris.

Biology: The species lives monoeciously on Artemisia vulgaris.

33. Cavariella konoi Takahashi, 1939: Tartu (ME87), 20.VI.1997, 3 apt and 1 al on Heracleum sosnowskyi; 24.VI.1997, 2 apt on Levisticum officinale; 28.VI.1997, 2 apt and 1 al on Aethusa cynapium; 12.VII.1998, 1 apt on Cnidium dubium; 15.VII.1998, 3 apt and 1 nymph (al) on Angelica atropurpurea.

The aphids were found in inflorescences or on upper parts of stems of A. cynapium, A. atropurpurea, C. dubium, H. sosnowskyi, and L. officinale.

Biology: The species is heteroecious alternating between Salix and Apiaceae.

34. Ovatus crataegarius (Walker, 1850): Tartu (ME87), 08.VIII.1997, 2 apt on Mentha arvensis.

The aphids were found in small numbers on the undersides of leaves of M. arvensis.

Biology: The species is heteroecious alternating between Crataegus and Mentha. 
35. Hyperomyzus pallidus Hille Ris Lambers, 1935: Tartu (ME87), 30.VII.1998, 3 apt on Sonchus arvensis.

The aphids were found singly or in small colonies on the undersides of lower leaves of $S$. arvensis.

Biology: The species is heteroecious alternating between Ribes alpinum and Sonchus arvensis.

36. Impatientinum asiaticum Nevsky, 1929: Tartu (ME87), 10.VIII.1992, 13.VIII.1992, 14.VIII.1992, 27.VIII.1992 and 06.VIII.1997, 4 apt and 1 al on Impatiens parviflora.

The species was found in great numbers on the upper parts of stems and pedicels of its host, I. parviflora.

Biology: The species lives monoeciously on Impatiens parviflora.

37. Cryptomyzus korschelti Börner, 1938: Tartu (ME87), 03.VI.1998, 2 apt on Ribes alpinum.

The species was found on yellow leaf galls of $R$. alpinum.

Biology: The species is heteroecious alternating between Ribes alpinum and Stachys sylvatica. Raised, vaulted leaf galls, which are red or yellow on the upper sides, are produced on the primary host in early summer.

38. Pleotrichophorus glandulosus (Kaltenbach, 1846): Tartu (ME87), 19.VII.1997, 2 apt on Artemisia vulgaris.

The aphids were found singly or in small groups on the undersides of lower leaves.

Biology: The species lives monoeciously on Artemisia vulgaris.

39. Acyrthosiphon knechteli (Börner, 1950): Tähtvere (ME77, Tartu county), 09.VII.1998, 4 apt on Vaccinium uliginosum.

A few specimens were collected on the upper parts of V. uliginosum.

Biology: The species lives monoeciously on Vaccinium uliginosum. According to Heikinheimo (1990) it has also been found on Chamaedaphne calyculata.

40. Aulacorthum flavum F. P. Müller, 1958: Tähtvere (ME77, Tartu county), 09.VII.1998, 2 apt on Vaccinium uliginosum.

Two specimens were found on the underside of leaves of $V$. uliginosum.

Biology: The species lives monoeciously on young shoots and on the underside of leaves of Vaccinium uliginosum.

41. Macrosiphum epilobiellum Theobald, 1923: Tartu (ME87), 22.VII.1997, 1 apt on Epilobium montanum.

One apterous viviparous female with larvae was found on pedicel of E. montanum.

Biology: The species lives monoeciously on Epilobium.

42. Macrosiphum trollii Börner, 1950: Tartu (ME87), 26.VII.1998, 5 apt on Trollius acaulis.

The aphids were found on the undersides of leaves of T. acaulis. This plant species is not a native host of M. trollii. T. acaulis grows naturally in the 
Himalayas, but it is grown also as a decorative plant elsewhere. Present findings are from the Botanical Garden of the University of Tartu.

Biology: The species lives monoeciously on Trollius europaeus.

43. Delphiniobium junackianum (Karsch, 1887): Tartu (ME87), 26.VII.1998, 3 apt and 1 al on Aconitum volubile; 27.VIII.1998, 2 apt and 1 al on A. napellus, A. paniculatum, and Delphinium sp.

The small-sized or medium-sized colonies were found on the pedicels of inflorescences of A. volubile and on fruits and undersides of leaves of A. napellus, A. paniculatum, and Delphinium sp.

Biology: The species lives monoeciously on Aconitum and Delphinium.

44. Macrosiphoniella artemisiae (Boyer de Fonscolombe, 1841): Tartu (ME87), 08.VII.1997, 4 apt and 22.VI.1998, 1 al on Artemisia vulgaris; 20.VII.1997, 1 apt and 1 al on $A$. absinthium.

The aphids were found only in small colonies in inflorescences of A. vulgaris.

Biology: The species lives monoeciously on upper parts of Artemisia vulgaris.

45. Macrosiphoniella oblonga (Mordvilko, 1901): Tartu (ME87), 06.VII.1998, 2 apt on Artemisia vulgaris.

The aphids were found singly on upper parts of stems of A. vulgaris.

Biology: The species lives monoeciously on Artemisia vulgaris and cultivated Chrysanthemum spp.

46. Macrosiphoniella sejuncta (Walker, 1848): Tartu (ME87), 09.VI.1998, 1 apt on Achillea millefolium.

Only one specimen was collected on a leaf of A. millefolium.

Biology: The species lives monoeciously on Achillea millefolium.

47. Macrosiphoniella tanacetaria (Kaltenbach, 1843): Tartu (ME87), 30.VII.1998, 1 al on Tanacetum vulgare.

One alate viviparous female and immature females were found in inflorescences of $T$. vulgare.

Biology: The species lives monoeciously on Tanacetum, Chrysanthemum, and Matricaria.

48. Uroleucon (U.) cirsii (Linné, 1758): Tartu (ME87), 26.VI.1997, nymphs (2 apt and 1 al) and 16.VII.1997, 3 apt on Cirsium arvense.

The aphids were found in large colonies on stems or undersides of leaves of C. arvense.

Biology: The species lives monoeciously on Cirsium.

49. Uroleucon (U.) hypochoeridis (Hille Ris Lambers, 1939): Tartu (ME87), 19.VII.1998, 4 apt on Leontodon autumnalis.

The small colonies of apterous viviparous females were found on upper parts of stems of L. autumnalis.

Biology: The species lives monoeciously on Hypochoeris and Leontodon autumnalis. 
50. Uroleucon (U.) tanaceti (Linné, 1758): Tartu (ME87), 03.VII.1998, 4 apt on Tanacetum vulgare.

The small colony of apterous females was found on the underside of a leaf of T. vulgare.

Biology: The species lives monoeciously on Tanacetum and cultivated Chrysanthemum spp.

51. Uroleucon (Uromelan) aeneum (Hille Ris Lambers, 1939): Tartu (ME87), 17.VII.1997, 2 apt on Carduus crispus.

The small colonies were found on upper parts of stems and undersides of leaves of C. crispus.

Biology: The species lives monoeciously on Carduus and Cirsium.

52. Uroleucon (Uromelan) nigrocampanulae (Theobald, 1928): Tartu (ME87), 04.VII.1998, 3 nymphs (apt) on Campanula trachelium.

Apterous nymphs were collected on a flower of $C$. trachelium.

Biology: The species lives monoeciously on Campanula.

53. Uroleucon (Uromelan) riparium (Stroyan, 1955): Tähtvere (ME77, Tartu county), 09.VII.1998, 2 nymphs (apt) on Crepis paludosa.

The small colony of immature apterous females was found on the pedicel of the inflorescence of $C$. paludosa.

Biology: The species lives monoeciously on Crepis paludosa and C. tectorum.

54. Uroleucon (Uromelan) taraxaci (Kaltenbach, 1843): Tartu (ME87), 07.VII.1997, 4 apt on Taraxacum officinale.

The very large colony of apterous females was found on the undersides of leaves and leaf-bases of $T$. officinale. It was attended by ants.

Biology: The species lives monoeciously on Taraxacum.

55. Metopeurum fuscovoride Stroyan, 1950: Tartu (ME87), 09.VII.1997, 3 apt and 2 al on Achillea millefolium; 11.VII.1997, 2 apt and 1 al on Tanacetum vulgare.

The large colonies, protected by ants, were found on upper parts of stems of T. vulgare and A. millefolium.

Biology: The species lives monoeciously on Tanacetum vulgare. It has occasionally been found (in Germany and Lithuania) on Achillea millefolium.

\section{Comments on distribution}

Aphis forbesi - Absent in Finland, not recorded in Sweden. Europe, including North Germany and Poland, south to Spain and former Yugoslavia; not in Britain. According to Rupais (1989) it has been found in Latvia.

Aphis newtoni - Recorded in Sweden but absent in Finland. Britain, Germany, Poland, former Czechoslovakia, Rumania, Switzerland. According to Rupais (1989) it has been found in Latvia. 
Aphis praeterita - Recorded in Sweden, absent in Finland. Europe, including Britain and Germany, south to Spain and former Czechoslovakia, east to the former USSR. According to Rupais (1989) it has been found in Latvia.

Anuraphis catonii-Recorded in Sweden (in Uppland), not recorded in Denmark, Norway, and Finland. Britain, Germany, Poland, Austria, North Italy, and the Ukraine. Not recorded in Latvia.

Brachycaudus tragopogonis - Recorded in Sweden, not in Finland. Europe, including Britain and North Germany, south to Spain and Hungary, east to Russia; Transcaucasia, Kazakhstan, West Siberia and Central Asia. According to Rupais (1989) it has been found in Latvia.

Dysaphis bonomii - The northernmost find of this species. Recorded in Denmark (East Jutland) and Sweden (Skåne). Not in Norway and Finland. Europe, including Britain, south to Italy. According to Rupais (1989) it has been found in Latvia.

Dysaphis devecta - Not recorded in Fennoscandia and Denmark. Europe, including Britain and The Netherlands, south to France and Rumania, east to the former USSR. According to Rupais (1989) it has been found in Latvia.

Macrosiphum trollii - Found in Sweden, North Germany, Finland, North Russia, and in high mountain areas farther south: Switzerland and Austria (Heie, 1994). Not recorded in Latvia and Lithuania. Its geographical distribution is adequate to the boreoalpine type.

\section{ACKNOWLEDGEMENTS}

I thank M. Martin and K. Elberg for reviewing this manuscript.

\section{REFERENCES}

Cholodkovsky, N. 1897a. Beiträge zu einer Monographie der Coniferen-Läuse. Part I. Horae Soc. Ent. Rossicae, 1896-1897, XXXI, 1-61.

Cholodkovsky, N. 1897b. On life cycles of aphids living on Ulmus. Horae Soc. Ent. Rossicae, 1896-1897, XXXI, LXXIII-LXXVII (in Russian).

Cholodkovsky, N. 1898a. First annotated catalogue of aphid (Aphidae) collections in Zoological Cabinet of St. Petersburg Institute of Forestry. Izv. Lesn. inst., 1, 31-54 (in Russian).

Cholodkovsky, N. 1898b. Beiträge zu einer Monographie der Coniferen-Läuse. Part II. Horae Soc. Ent. Rossicae, 1896-1897, XXXI, 603-674.

Cholodkovsky, N. 1902. Second annotated catalogue of aphid (Aphidae) collections in Zoological Cabinet of St. Petersburg Institute of Forestry. Izv. Lesn. inst., 8, 49-59 (in Russian).

Daniel, O. 1935. Metsakaitse. Tartu.

Elberg, K. 1992. Mis on juhtunud paplilehega? Eesti Loodus, 7/8, 423-424.

Elberg, K. 1995. Maismaaselgrootud. In Eesti. Loodus (Raukas, A., ed.), pp. 452-461. Valgus, Eesti Entsüklopeediakirjastus, Tallinn. 
Haberman, H., Krall, E., Maavara, V., Martin, A., Remm, E., Remm, H., Siitan, V., Viidalepp, J. \& Vilbaste, A. 1985. Matsalu märgala maismaaselgrootud. In Matsalu - rahvusvahelise tähtsusega märgala (Kumari, E., ed.), pp. 140-198. Valgus, Tallinn.

Heie, O. E. 1980. The Aphidoidea (Hemiptera) of Fennoscandia and Denmark. I. General part. The families Mindaridae, Hormaphididae, Thelaxidae, Anoeciidae and Pemphigidae. In Fauna Entomologica Scandinavica, 9. Scandinavian Science Press, Klampenborg.

Heie, O. E. 1982. The Aphidoidea (Hemiptera) of Fennoscandia and Denmark. II. The family Drepanosiphidae. In Fauna Entomologica Scandinavica, 11. Scandinavian Science Press, Klampenborg.

Heie, O. E. 1986. The Aphidoidea (Hemiptera) of Fennoscandia and Denmark. III. Family Aphididae: subfamily Pterocommatinae and tribe Aphidini of subfamily Aphidinae. In Fauna Entomologica Scandinavica, 17. Scandinavian Science Press, Copenhagen.

Heie, O. E. 1992. The Aphidoidea (Hemiptera) of Fennoscandia and Denmark. IV. Family Aphididae: Part 1 of tribe Macrosiphini of subfamily Aphidinae. In Fauna Entomologica Scandinavica, 25. Scandinavian Science Press, Leiden, New York, Kobenhavn, Köln.

Heie, O. E. 1994. The Aphidoidea (Hemiptera) of Fennoscandia and Denmark. V. Family Aphididae: Part 2 of tribe Macrosiphini of subfamily Aphidinae. In Fauna Entomologica Scandinavica, 28. E. J. Brill, Leiden, New York, Köln.

Heie, O. E. 1995a. The Aphidoidea (Hemiptera) of Fennoscandia and Denmark. VI. Family Aphididae: Part 3 of tribe Macrosiphini of subfamily Aphidinae, and family Lachnidae. In Fauna Entomologica Scandinavica, 31. E. J. Brill, Leiden, New York, Köln.

Heie, O. E. 1995b. The composition of the aphid fauna of Fennoscandia and Denmark. Entomol. Fenn., 6, 2/3, 119-121.

Heikinheimo, O. 1990. Aphid species and morphs new to the fauna of Finland (Homoptera, Aphididae, Macrosiphini). Entomol. Fenn., 1, 2, 65-98.

Heikinheimo, O. 1997. Further species of Aphidoidea (Hom.) new to Finland. Entomol. Fenn., 7, 159-185.

Jaama, A., Kikas, L., Kuusksalu, R., Tava, V. \& Villemsoo, A. 1973. Taimekaitse käsiraamat. Valgus, Tallinn.

Kruus, M. 1988. Suuremõisa pargi kahjurid. In Eesti saarte loodus ja selle ressursside kasutamine (Kalamees, K., ed.), pp. 122-135. Eesti Looduseuurijate Seltsi aastaraamat, 72. Valgus, Tallinn.

Kuusksalu, R., Kõverjalg, E., Leivategija, L., Paide, T., Randalu, I. \& Tammaru, I. 1982. Taimekaitse. Valgus, Tallinn.

Lepik, E. \& Zolk, K. 1937. Taimekaitse. Loodus, Tartu.

Maavara, V., Merihein, A., Parmas, H. \& Parmasto, E. 1961. Metsakaitse. Eesti Riiklik Kirjastus, Tallinn.

Opmanis, K. 1928. Ein Beitrag zur Kenntnis der Aphidenfauna Lettlands. Acta Univ. Latv., XVIII (Riga).

Rupais, A. A. 1968. Harmful aphids (Aphidinea) on ornamental trees and shrubs in parks of Estonian SSR. In Abstracts of Reports of 6th Baltic Conference of Plant Protection. I, pp. 116-118. Tartu (in Russian).

Rupais, A. A. 1972. Materials on fauna of Estonian dendrophilous aphids. In Latvijas Entomologs. Suppl. II. Zinatne, Riga (in Russian).

Rupais, A. 1989. The aphids (Aphidodea) of Latvia. Zinatne, Riga (in Russian).

Rupais, A. \& Juronis, V. 1984. New and rare aphid species in the East Baltic region. Latv. Entomol., 27, 81-88 (in Russian).

Vilbaste, J. 1979. The Hemipteroidea of the Vooremaa hardwood-spruce forest. In Spruce Forest Ecosystem Structure and Ecology. 2. Basic Data on the Estonian Vooremaa Project (Frey, T., ed.), pp. 70-94. Tartu. 


\title{
Uusi andmeid Eesti lehetäiliste (Homoptera, Aphidodea) kohta
}

\author{
Tarmo Tiido
}

Senini oli Eestis lehetäiliste ülemsugukondade Phylloxeroidea ja Aphidoidea liikide teadaolevaks arvuks 185. Siinses artiklis on esitatud leiuandmed 55 lehetäiliigi kohta, mis puuduvad senistes Eesti lehetäisid käsitlevates publikatsioonides. Seitsme liigi puhul, mis tõenäoliselt jõuavad Eestis oma leviku põhjapiirile, on toodud andmed nende leviku kohta naabermaades. Liik Macrosiphum trollii Börn. on boreoalpiinse levikuga: seda on leitud Soomest, kuid mitte Lätist ega Leedust. 